\title{
Prospective of Herbal Medicine in Egypt
}

\section{Nada M Mostafa and Abdel Nasser Singab*}

Department of Pharmacognosy, Faculty of Pharmacy, Ain Shams University, Cairo, Egypt

\begin{abstract}
The great genetic biodiversity of medicinal plants found in Egypt played an important role in the use of Egyptian herbal medicines throughout the years. The ancient Egyptians, used them in therapy protocols, which were clarified in their papyri and tombs walls; and passing by the modern prescriptions, trends were found for using traditional alternatives to costly medications, either alone or as supplements accompanying the chemical drugs in the treatment protocols. Though many challenges are found in Egypt for herbal medicine industry and marketing, as lack of scientific evidence, quality standards, marketing strategies, extensive documentation to protect intellectual property and post-harvesting technologies; yet good agriculture practice, proper marketing plans, and modern molecular technologies can help the efficient use of those medicinal plants and their exportation worldwide, fetching a high income source to Egypt for carrying out more scientific research in agriculture and developing green technologies to produce pollution-free medicinal plants.
\end{abstract}

Keywords: Herbal medicine; Egypt; Challenges; Future prospective; Medicinal plants

\section{Introduction}

\section{Ancient Egyptians' herbal medicine}

The ancient Egyptians had used a various number of herbs in their medicines; which was clearly explained in their papyri. These included frankincense, fennel, linseed, castor oil, aloe, senna, henna, myrrh, thyme and many others [1]. Ancient Egyptians consumed a lot of garlic and onions for their belief that they treat problems of the respiratory and digestive systems, respectively; this was exemplified by the presence of garlic cloves in Tutankhamen tomb [1]. In addition, honey, milk, and egg were used in preparing drugs. Herbs were added to wine to macerate, and then drank as medicine [2]. They used minerals and all plant organs as leaves, flowers, roots, seeds, and fruits; applying them in various pharmaceutical forms as creams, pastes, lotions, teas, drops and others [3].

\section{Herbal medicine in modern ages}

In modern medicines, physicians weren't common with the use of herbal medicines in their prescriptions because they considered them as folk traditional medicines. Most of the herbal drugs have been registered as food supplements instead of drugs [4]. Nowadays, a coming back thought of the importance of herbal medicines beside conventional medicines, offering safe, fewer side effects, and low-cost effective drugs.

The World Health Organization (WHO) stated that health goals can't be achieved without the incorporation of herbal medicines and that $80 \%$ of the population depend on them for their health care [5].

Generally, rural people in developing countries are obliged to the use of medicinal plants for their remedies due to their poverty and lack availability of modern medicines [6]. Egypt being a developing country has a demand for herbal medicines as large as that for developed countries which are seeking for alternatives from traditional medicine. A clear example is that St. John's wort is twice prescribed in Germany than the drug Prozac ${ }^{\bullet}$ for anti-depression [5]. Additionally, the use of herbal medications can help in the cure of one of the highest prevalence viral infections (Hepatitis C) found in Egypt, where herbs can aid in regenerating the liver tissue after the medical eradication of the virus and can help in the relief of the used drugs side effects in the treatment protocol [7].

\section{Biodiversity of Egyptian medicinal plants}

There are abundance and biodiversity of medicinal and aromatic plants in Egypt, as reported in Flora of Egypt [8-12], for its geographical position, new available reclaimed areas, climatic, soil conditions, qualified scientists, new technologies and low-cost manufacture. In addition, numerous plants were introduced to Egypt and acclimatized [13]. All these criteria made Egypt to be considered as a potential site for exporting these herbs and medicinal plants, but there is a fear of depletion, slaughter harvesting, and extinction of these herbal medicines [5].

\section{Challenges for herbal medicine industry and marketing}

Moreover, many challenges are found in Egypt for herbal medicine industry and marketing, including the lack of scientific evidence, quality standards, marketing strategies for many traditional medicines; the need for extensive deep documentation to protect intellectual property of these medicines by patents; and developing post-harvesting technologies for storage, packaging and processing of the medicinal plants $[14,15]$. A higher income will be fetched to Egypt if its exports of the medicinal plants are processed instead of being raw material. Herbal extracts represent about 33\% of the Egyptian exports of medicinal plants [5].

\section{Criteria needed for efficient herbal medicine industry}

This leads us to think of the need for good agriculture practice; more clinical trials; studies on the synergistic effects and contraindications of herbs; more pharmacological research on newly isolated compounds and/ or extracts [16-20]; the application of green technologies, rapid high performance extraction methods, especially with increasing risk of solvent pollutions and increasing the costs of energy worldwide [21]; applying standardization of plant extracts and new drug delivery systems [22,23]; and the use of modern technologies as molecular pharmacognosy in the fields of solving taxonomical problems of

*Corresponding author: Singab AN, Department of Pharmacognosy, Faculty of Pharmacy, Ain Shams University, 11566, Cairo, Egypt, Tel: +20224051120; E-mail: abdelnasser.sengab@pharma.asu.edu.eg

Received March13, 2018; Accepted March 19, 2018; Published April 13, 2018

Citation: Mostafa NM, Singab AN (2018) Prospective of Herbal Medicine in Egypt. Med Chem (Los Angeles) 8: 116-117. doi: 10.4172/2161-0444.1000502

Copyright: (c) 2018 Mostafa NM, et al. This is an open-access article distributed under the terms of the Creative Commons Attribution License, which permits unrestricted use, distribution, and reproduction in any medium, provided the original author and source are credited. 
variety confusion; increasing yield, quality and growth of medicinal plants; conservation of the endangered species, controlling the plant metabolic pathways, biosynthesis of secondary metabolites and producing pollution-free medicinal plants [24].

\section{Conclusion}

We conclude that, Egypt represents a country with great plant biodiversity and a central core for the use of traditional herbal medicine throughout the decades. Yet, appropriate planning strategies should be undertaken for the efficient use of these medicinal plants and herbs locally; their marketing and exportation globally for mutual benefit purposes.

\section{References}

1. Abou El-Soud NM (2010) Herbal medicine in ancient Egypt. J Med Plant Res 4: $82-86$

2. Nunn JF (1996) Ancient Egyptian Medicine. British Museum Press, London.

3. Dagmar L (2006) International Trade in Medicinal and Aromatic Plants. Actors, Volumes and Commodities, Plants. In: Medicinal and Aromatic Plants. Bogers RJ, Craker LE, Lange D (eds.). Springer, New York, p: 155.

4. Haggag MY (2004) Herbal medicine in Egypt. Iran J Pharm Res 3: 5-6.

5. Abdel-Azim NS, Shams KA, Shahat AAA, El Missiry MM, Ismail SI, et al. (2011) Egyptian Herbal Drug Industry: Challenges and Future Prospects. Res J Med Plant 5: 136-144

6. Harbir S (2006) Prospects and challenges for harnessing opportunities in medicinal plants sector in India. Law Environ Dev J 2: 198-211.

7. Mostafa NM, Singab AN (2016) After HCV Eradication with Sovaldi®, Can Herbs Regenerate Damaged Liver, Minimize Side Effects and Reduce the Bill? Med Aromat Plants 5: 257.

8. Tackholm V (1974) Student's Flora of Egypt. Cairo University Press, Cairo, Egypt.

9. Boulos L (1999) Flora of Egypt. Vol. 1, Al-Hadara Publishing, Cairo, Egypt.

10. Boulos L (2002) Flora of Egypt. Vol. 3, Al-Hadara Publication, Cairo, Egypt.
11. Boulos L (2005) Flora of Egypt. Vol. 4, Al-Hadara Publication, Cairo, Egypt.

12. Boulos L (2000) Flora of Egypt. 2nd edn. Al-Hadara Publication, Cairo, Egypt.

13. Shams KA, Nazif NM, Abdel-Azim NS, Abdel-Shafeek KA, El-Missiry MM, et al. (2009) Isolation and characterization of antineoplastic alkaloids from Catharanthus roseus L. Don. cultivated in Egypt. Afr J Tradit Complement Altern Med 6: 118-122.

14. Samal PK, Shah A, Tiwari SC, Agrawal DK (2004) Indigenous healthcare practices and their linkage with bioresource conservation and socio-economic development in Central Himalayan region of India. Indian J Tradit Know 3: 12 26.

15. Green EC, Goodman KJ, Hare M (1999) Ethnobotany, IPR and benefit sharing The forest people fund in Suriname. Indigen Knowledge Dev Monit 7: 8-11.

16. Mostafa NM, Ashour ML, Eldahshan OA, Singab AN (2015) Cytotoxic activity and molecular docking of a novel biflavonoid isolated from Jacaranda acutifolia (Bignoniaceae). Nat Prod Res 23: 1-8.

17. Singab AN, Ayoub NA, Ali EN, Mostafa NM (2010) Antioxidant and hepatoprotective activities of Egyptian moraceous plants against carbon tetrachloride-induced oxidative stress and liver damage in rats. Pharm Biol 48: 1255-1264.

18. Mostafa NM, Eldahshan OA, El-Beshbishy HA, Singab AN (2017) Hepatoprotective, Antihyperglycemic and Cytotoxic Activities of Jacaranda acutifolia Leaf Extract. Med Aromat Plants (Los Angles) 6: 297.

19. Mostafa NM, Abd El-Ghffar EA, Hegazy HG, Eldahshan OA (2018) New methoxyflavone from Casmiora sapota and the biological activities of its leaves extract against lead acetate induced hepatotoxicity in rats. Chem Biodivers.

20. Mostafa NM (2018) $\beta$-Amyrin rich Bombax ceiba leaf extract with potential neuroprotective activity against scopolamine-induced memory impairment in rats. Rec Nat Prod.

21. Wang L, Weller CL (2006) Recent advances in extraction of nutraceuticals from plants. Trends Food Sci Technol 17: 300-312.

22. Mostafa NM (2017) Comparative analysis of rutin content in some Egyptian plants: A validated RP-HPLC-DAD approach. European J Med Plants 19: 1-8.

23. Ishak RAH, Mostafa NM, Kamel AO (2017) Stealth lipid polymer hybrid nanoparticles loaded with rutin for effective brain delivery - comparative study with the gold standard (Tween 80 ): optimization, characterization and biodistribution. Drug Deliv 24: 1874-1890.

24. Singab AN, Mostafa NM (2016) Molecular Pharmacognosy: A Promising and Prospective Scope in the Field. Med Aromat Plants 5: e172. 